\title{
KERAGAMAN JUMLAH ANAK SEKELAHIRAN DAN BOBOT LAHIR BANGSA BABI GALUR MURNI AUSTRALIA
}

\author{
(Litter Size and Birth Weight Variances of Australian Pure Breed Swine)
}

\author{
Eva Diana Manik ${ }^{1}$, Hamdan $^{2}$, dan Usman Budi ${ }^{2}$
}

1. Mahasiswa Program Studi Peternakan Fakultas Pertanian Universitas Sumatera Utara

2. Staf Pengajar Program Studi Peternakan Fakultas Pertanian Universitas Sumatera Utara

\begin{abstract}
Swine is a business-majority of districts Siborong borong, where most of the sources livestock derived from livestock breeding centers, so that must be known that there is a great variety among the breed of swines and then obtained the greatest most superior of superior livestock to increase the productivity of swine pure breed. This research was conducted at the livestock breeding centers Swine and Buffaloes Installation Sinur, Siaro village Siborong-borong starting in May-September 2012 using a survey method. Material used were direct observational piglets data from May to September 2012 (primary data) and piglets recording data time series ranging from 2009 through 2011 (secondary data). Breed used were Landrace, Yorkshire, Duroc and Berkshire as much as 10 head sows per breed. Parameters measured were variance, the litter size and birth weight. The Results showed that the variances of litter size and birth weight Australian pure breed swine between in medium to high every year. The greatest variance range mean values found in Duroc breed about 0.1 for birth weight (coefficient variances \pm $19,48 \%$ ) and 7.73 for litter size (coefficient variances $\pm 35,77 \%$ ). The best kinds of swine can be used as breeding is Yorkshire breed because it have litter size per birth very high and nature of parental (mothering ability) is good and kind of breed that can be considered to selected is Duroc breed.
\end{abstract}

Keywords: Variance, litter size and birth weight

\begin{abstract}
ABSTRAK
Peternakan babi merupakan usaha mayoritas penduduk kecamatan Siborong-borong, dimana sumber bibit ternak kebanyakan diperoleh dari Balai Pembibitan Ternak Unggul, sehingga perlu diketahui besar keragaman yang terdapat diantara bangsa ternak babi kemudian diperoleh ternak terunggul dari yang unggul sehingga dapat meningkatkan produktivitas. Penelitian ini dilaksanakan di BPTU Babi dan Kerbau Sinur desa Siaro kecamatan Siborong-borong mulai bulan Mei sampai dengan September 2012 menggunakan metode survey. Materi yang digunakan adalah data pengamatan langsung anak babi mulai bulan Mei sampai dengan September 2012 (data primer) dan pencatatan data time series anak babi mulai dari tahun 2009 sampai dengan 2011 (data sekunder). Jenis babi yang digunakan adalah bangsa babi Landrace, Yorkshire, Duroc dan Berkshire sebanyak 10 ekor induk per bangsa babi. Parameter yang diamati adalah ragam, jumlah anak sekelahiran dan bobot lahir. Hasil penelitian menunjukkan bahwa keragaman bobot lahir dan jumlah anak sekelahiran bangsa babi galur murni Australia bervariasi antara sedang sampai dengan tinggi tiap tahun. Rataan nilai ragam paling besar terdapat pada bangsa babi Duroc yaitu sebesar 0,1 untuk bobot lahir (koefisien keragaman $\pm 19,48 \%$ ) dan 7,73 untuk jumlah anak sekelahiran (koefisien keragaman $\pm 35,77$ ). Jenis babi terbaik yang dapat digunakan sebagai pembibit adalah bangsa Yorkshire karena mempunyai jumlah anak sekelahiran yang tinggi dan sifat keindukan (mothering ability) yang baik dan jenis babi yang dapat dipertimbangkan untuk diseleksi adalah jenis babi Duroc.
\end{abstract}

Kata kunci : Ragam, jumlah anak sekelahiran, bobot lahir 


\section{PENDAHULUAN}

Ternak babi merupakan hewan politokus yang potensial memberikan sumbangan berarti bagi peningkatan produksi daging dalam upaya pemenuhan kebutuhan protein hewani asal ternak di Indonesia. Walaupun demikian, produktivitas ternak babi masih belum optimal yang tergambar dari masih tingginya kematian embrio selama periode kebuntingan dan kematian anak prasapih serta cenderung semakin tinggi jumlah anak sekelahiran semakin besar persentase anak yang lahir di bawah bobot normal (Geisert dan Schmitt, 2002). Oleh karena itu sangat diperlukan suatu langkah strategis untuk memperbaiki produksi babi yang antara lain dengan memperbaiki produktivitas induk.

Ternak babi merupakan salah satu komoditas peternakan yang cukup potensial untuk dikembangkan. Ternak babi dan atau produk olahannya cukup potensial sebagai komoditas ekspor nasional. Pasar komoditas ini masih terbuka lebar ke berbagai negara seperti Singapura dan Hongkong. Berdasarkan statistik peternakan tahun 2010, populasi ternak babi tertinggi terdapat di Provinsi Nusa Tenggara Timur 1,637,351 ekor, Bali (930,465 ekor), Sumatera Utara (734,222 ekor), Sulawesi Selatan (549,083 ekor), Kalimantan Barat (484,299 ekor), Papua (546,696 ekor), Sulawesi Utara (332,942 ekor), Bangka Belitung (268,220 ekor), Sulawesi Tengah (215,973 ekor), Kepri (185,663 ekor) (Ditjennak, 2011).

Bangsa babi memiliki sifat-sifat kualitatif yang berbeda antar bangsa dan relatif seragam dalam bangsanya. Diantara sifat-sifat tersebut yang diinginkan peternak adalah sifat yang bermanfaat dan bermakna ekonomi, seperti daya produksi, jumlah dan bobot anakan saat lahir, disapih dan dibesarkan atau pertumbuhan, mortalitas rendah serta efisiensi penggunaan makanan yang tinggi. Produktivitas inilah yang selalu diusahakan ditingkatkan melalui perbaikan genetis dengan jalan seleksi dan perkawinan serta melalui perbaikan lingkungannya. Untuk mencapai sasaran tingkat produktivitas yang diinginkan maka semua faktor penentu dikaji potensinya dan melalui tehnik pelaksanaan diramalkan prospeknya melalui penerapan syarat-syarat mutu bibit yang lazim dilakukan pada pusat pembibitan ternak (Siagian 1985).

Produktivitas babi dinilai dari jumlah dan bobot anak lahir dan disapih, laju pertumbuhan dan mortalitas. Efisiensi makanan di nilai dari jumlah makanan yang diberikan selama laktasi oleh tiap induk yang dibebankan per ekor atau tiap kilogram kenaikan bobot badan anak selama laktasi. Peningkatan produktivitas babi biasanya dengan jalan persilangan, dengan maksud untuk 
mendapatkan pengaruh heterosis terutama terhadap jumlah anak seperlahirannya (Hardjosubroto, 1994).

Keberhasilan di dalam usaha ternak babi adalah juga sangat tergantung kepada pemeliharaan induk dan pejantan yang memiliki sifat-sifat baik. Oleh karena itu para peternak yang maju, tentu saja akan selalu mengadakan seleksi terhadap ternaknya. Seleksi berarti memilih hewan ternak yang bernilai tinggi, yakni memilih babi-babi yang menguntungkan. Dengan seleksi itu diharapkan ada perbaikan karakter ekonomi tertentu. Di dalam suatu usaha untuk memajukan dan mengembangkan ternak babi, para peternak bukanlah sekedar memperbanyak atau mengembangbiakkan ternaknya, melainkan sekaligus memuliakan ternak (mengupgrade). Dalam hal ini, semua babi induk dan pejantan yang hendak dikawinkan harus dilakukan seleksi terlebih dahulu. Dengan demikian perkawinan bukan terjadi secara kebetulan atau liar, melainkan diatur dan terarah (Sihombing, 1997).

\section{BAHAN DAN METODE PENELITIAN}

\section{Lokasi dan Waktu Penelitian}

Penelitian ini dilaksanakan di Balai Penelitian Ternak Unggul (BPTU) Sinur, desa Siaro, Kecamatan Siborong-borong, Kabupaten Tapanuli Utara, sekitar 255-260 km dari kota Medan dengan ketinggian lokasi sekitar $1250 \mathrm{~m}$ diatas permukaan laut, dengan suhu berkisar $20-25^{\circ} \mathrm{C}$. Penelitian ini dilaksanakan mulai bulan Mei sampai dengan September 2012.

\section{Bahan dan Alat Penelitian}

Bahan yang digunakan dalam penelitian ini adalah bangsa babi galur murni Australia (Landrace, Yorkshire, Duroc dan Berkshire) sebanyak 10 ekor per bangsa di Balai Pembibitan Ternak Unggul (BPTU) Sinur, desa Siaro dan data time series jumlah anak sekelahiran selama 4 tahun.

Peralatan yang digunakan adalah timbangan dengan kapasitas $10 \mathrm{~kg}$ untuk menimbang bobot lahir ternak yang baru lahir, kamera digital sebagai alat dokumentasi pada saat penelitian dilaksanakan, buku dan alat tulis untuk mencatat hasil penimbangan, dan kalkulator untuk menghitung data sementara. 


\section{Metode Penelitian}

Metode penelitian yang digunakan adalah metode survei dengan menggunakan data primer dan data sekunder. Pengumpulan data sekunder dilakukan secara acak untuk masingmasing bangsa babi melalui recording. Sebagai dasar pengambilan adalah dengan mengambil 10 data dari kartu recording untuk tiap parameter yang digunakan pada setiap bangsa babi. Data sekunder ini diperoleh dari instansi terkait dengan menggunakan data time seri, yaitu menggunakan data recording jumlah anak sekelahiran selama 4 tahun. Data primer diperoleh dengan dengan pengamatan dan pengukuran langsung terhadap sampel. Pengambilan sampel dilakukan secara sensus dari keempat bangsa babi galur murni yang ada di BPTU Sinur Siborong-borong. Data primer diperoleh dari monitoring terhadap kegiatan beranak keempat bangsa ternak babi. Setiap anak babi yang baru lahir dari keempat jenis babi tersebut akan dilakukan penanganan seperlunya, yaitu segera membersihkan dari selaput lendir yang menutup mulut dan hidung, di potong tali pusat dan gigi susunya lalu kemudian ditimbang dengan menggunakan timbangan.

\section{Analisis Data}

Pengolahan data bobot lahir dan jumlah anak sekelahiran ternak babi dihitung dengan menggunakan rumus Ragam dan analisis regresi linier sederhana. Analisis regresi linier sederhana adalah hubungan secara linear antara satu variabel independen $(\mathrm{X})$ dengan variabel dependen (Y). Analisis ini untuk mengetahui arah hubungan antara variabel independen dengan variabel dependen apakah positif atau negatif dan untuk memprediksi nilai dari variabel dependen apabila nilai variabel independen mengalami kenaikan atau penurunan. Data yang digunakan biasanya berskala interval atau rasio. Rumus regresi linear sederhana sebagai berikut:

$$
\mathrm{Y}=\mathrm{a}+\mathrm{bX}+\mathrm{e}
$$

Keterangan:

$\mathrm{Y}=$ Variabel dependen (nilai yang diprediksikan)

$\mathrm{X}=$ Variabel independen

a $=$ Konstanta (nilai $\mathrm{Y}$ apabila $\mathrm{X}=0$ )

$\mathrm{b}=$ Koefisien regresi (nilai peningkatan ataupun penurunan)

e $=$ Variabel yang tidak diteliti 
Besar nilai ragam diperoleh dengan menghitung besar rataan masing-masing bobot lahir dan jumlah anak sekelahiran.

$$
\bar{x}=\frac{\sum_{i=1}^{n} x_{i} f_{i}}{\sum_{i=1}^{n} f_{i}}
$$

Keterangan:

$$
\mathrm{fi}=\text { frekuensi kelas ke-i } \quad \mathrm{xi}=\text { data } \mathrm{ke}-i \quad \mathrm{n}=\text { banyak data }
$$

Ragam ialah rata-rata jumlah kuadrat simpangan data dari pusatnya. Rumus dari ragam ialah sebagai berikut:

$$
s^{2}=\frac{\sum_{i=1}^{n}\left(X_{i}-\bar{X}\right)^{2}}{n-1}
$$

Keterangan :

$\mathrm{S}^{2} \quad=$ ragam (variance)

$\mathrm{n} \quad=$ ukuran data

$\mathrm{n}-1=$ derajat bebas (degrees of freedom)

$\mathrm{x}^{-} \quad=$ rataan hitung

$X_{i} \quad=$ data ke- $i$ dari $X_{1}, X_{2}, X_{3}, \ldots, X_{n}$

(Sastrosupardi, 2000).

Selanjutnya dihitung besar Koefisien Keragamannya. Koefisien Keragaman Standar deviasi dihitung dengan formula berikut:

$$
K K=C . V=\frac{s}{\bar{x}} \times 100 \%
$$

Keterangan :

$$
\mathrm{S}=\text { simpangan baku } \quad \mathrm{x},{ }^{-}=\text {rataan }
$$

Koefisien keragaman (KK) merupakan ukuran yang bebas satuan dan selalu dinyatakan dalam bentuk persentase. Nilai KK yang kecil menunjukkan bahwa data tidak terlalu beragam dan lebih konsisten. KK tidak dapat diandalkan apabila nilai rata-rata hampir sama dengan 0 (nol). KK juga tidak stabil apabila skala pengukuran data yang digunakan bukan skala rasio. 


\section{Parameter Penelitian}

Parameter dalam penelitian ini adalah : ragam, jumlah anak sekelahiran dari satu induk yang melahirkan (ekor/induk/kelahiran) dan bobot lahir dari keempat bangsa babi di BPTU Sinur Siborong-borong, yang ditimbang waktu anak lahir sebelum menyusui (kg).

\section{HASIL DAN PEMBAHASAN}

\section{Rekapitulasi Hasil Penelitian}

Hasil penelitian keragaman jumlah anak sekelahiran dan bobot lahir dari bangsa babi galur murni Australia dapat dilihat pada tabel di bawah ini.

Tabel 1. Rekapitulasi Parameter

\begin{tabular}{|c|c|c|c|c|c|}
\hline \multirow[t]{2}{*}{ No. } & \multirow[t]{2}{*}{ Parameter } & \multicolumn{4}{|c|}{ Bangsa Babi } \\
\hline & & Landrace & Yorkshire & Duroc & Berkshire \\
\hline 1. & Ragam bobot lahir anak & & & & \\
\hline \multirow{10}{*}{2.} & - $\quad$ Tahun 2012 & 0,101 & 0,059 & 0,27 & 0,081 \\
\hline & - $\quad$ Tahun 2011 & 0,053 & 0,024 & 0,01 & 0,015 \\
\hline & - $\quad$ Tahun 2010 & 0,037 & 0,030 & 0,09 & 0,002 \\
\hline & - $\quad$ Tahun 2009 & 0,073 & 0,016 & 0,03 & 0,047 \\
\hline & Total Rataan & 0,264 & 0,129 & 0,4 & 0,145 \\
\hline & $\begin{array}{l}\text { Ragam jumlah anak } \\
\text { sekelahiran }\end{array}$ & & & & \\
\hline & - $\quad$ Tahun 2012 & 5,12 & 2,75 & 16,7 & 1,62 \\
\hline & - $\quad$ Tahun 2011 & 4,44 & 5,21 & 2,33 & 2,8 \\
\hline & - $\quad$ Tahun 2010 & 3,43 & 4,44 & 5,33 & 5,58 \\
\hline & - $\quad$ Tahun 2009 & 3,88 & 6,57 & 6,56 & 4,55 \\
\hline \multirow[b]{2}{*}{3.} & Total rataan & 16,87 & 18,97 & 30,92 & 14,55 \\
\hline & $\begin{array}{l}\text { Koefisien Keragaman } \\
\text { bobot lahir }\end{array}$ & & & & \\
\hline \multirow{10}{*}{4.} & - $\quad$ Tahun 2012 & 20,13 & 13,48 & 37,66 & 19,01 \\
\hline & - $\quad$ Tahun 2011 & 14,33 & 8,89 & 8,22 & 8,90 \\
\hline & - $\quad$ Tahun 2010 & 12,32 & 10.44 & 18,12 & 2,95 \\
\hline & - $\quad$ Tahun 2009 & 17,45 & 7 & 13,92 & 15,26 \\
\hline & Total Rataan & 64,23 & 88 & 77,92 & 46,12 \\
\hline & $\begin{array}{l}\text { Koefisien Keragaman } \\
\text { jumlah anak sekelahiran }\end{array}$ & & & & \\
\hline & - $\quad$ Tahun 2012 & 30,96 & 21,64 & 65,97 & 16,78 \\
\hline & - $\quad$ Tahun 2011 & 30,14 & 28,86 & 14,85 & 22,57 \\
\hline & - $\quad$ Tahun 2010 & 30,33 & 24,25 & 26,53 & 30,45 \\
\hline & - $\quad$ Tahun 2009 & 24,94 & 28,44 & 35,75 & 27,92 \\
\hline \multirow[b]{2}{*}{5.} & Total Rataan & 116,37 & 103,19 & 143,1 & 97,72 \\
\hline & $\begin{array}{l}\text { Korelasi bobot lahir dan } \\
\text { jumlah anak sekelahiran }\end{array}$ & $-0,48 \_$ &, 330 & $-0,508$ & $-0,371$ \\
\hline
\end{tabular}




\section{Bobot Lahir dan Jumlah Anak Sekelahiran}

Bobot lahir adalah bobot dari hasil penimbangan anak babi pada waktu lahir sesaat sebelum dilepaskan ke induknya untuk menyusui yang dihitung dalam kilogram. Jumlah anak sekelahiran diperoleh dari banyaknya jumlah anak pada saat kelahiran. Jumlah anak sekelahiran pada ternak babi perlu diperhatikan, karena sifat ini mempengaruhi sifat bobot lahir. Jumlah anak sekelahiran diperoleh dari banyaknya jumlah anak pada saat melahirkan. Jumlah anak sekelahiran pada ternak babi perlu diperhatikan, karena sifat ini mempengaruhi sifat bobot lahir.

\section{Landrace}

Rataan bobot lahir babi bangsa Landrace tertinggi selama 4 tahun berada pada tahun 2011 yaitu 1,614 kg/ekor/kelahiran, sementara ragam bobot lahir paling tinggi pada bangsa babi Landrace sebesar 0,101 terdapat pada induk babi Landrace tahun 2012 dengan koefisien keragaman sebesar 20,13\%. Bobot lahir dengan berat 1,614 kg/ekor/kelahiran tergolong tinggi sesuai dengan pernyataan Sihombing (1997) yang menyatakan bahwa besarnya rataan bobot lahir anak babi bervariasi antara 1,09-1,77 kg. Nilai ragam bobot lahir yang rendah berarti hampir homogennya bobot lahir sekelahiran yang dihasilkan induk babi Landrace. Hal ini ditunjukkan dengan kecilnya nilai ragam yang dihasilkan masing-masing induk babi per tahunnya. Hampir homogen menjelaskan bahwa sifat dua ternak babi itu tidak benar-benar serupa dan seragam karena masih ada pewarisan-pewarisan sifat yang berbeda antara induk yang satu dengan yang lain terhadap turunannya, sesuai dengan pernyataan Sihombing (1997) yang menyatakan bahwa besarnya variasi sifat-sifat yang mungkin diwariskan pada babi menjelaskan kecilnya kesempatan dua individu benar-benar serupa meskipun sesama sekelahiran dari induk.

Rata-rata jumlah anak sekelahiran babi Landrace Australia secara berurutan yaitu 7,3 ekor, 7 ekor, 6,1 ekor dan 7,9 ekor. Jumlah anak sekelahiran selama penelitian tergolong rendah karena semua induk babi dalam keadaan muda (induk baru). Diasumsikan bahwa sebagian besar induk pada saat pengambilan data dilakukan adalah induk yang baru pertama kali melahirkan. Hal ini sesuai dengan pernyataan Babot et al (1994) yang menyatakan bahwa jumlah anak babi per kelahiran pada kelahiran pertama bervariasi antara 6,71-9,45 ekor bagi bangsa murni dan angka ini akan naik sampai induk berumur 3 tahun atau kelahiran ke 5 yang bervariasi antara $8,32-12,43$ ekor. 


\section{Yorkshire}

Rataan bobot lahir babi Yorkshire tertinggi pada tahun pertama (2012) yaitu 1,805 $\mathrm{kg} / \mathrm{ekor} /$ kelahiran. Sementara ragam dan koefisien keragaman tertinggi dari bobot lahir bangsa babi Yorkshire Australia sebesar 0,059 dan 13,48\% terdapat pada tahun 2012. Rataan jumlah anak sekelahiran tertinggi berada pada tahun 2009 yaitu sebanyak 9 ekor perkelahiran. Bobot lahir yang tinggi tergantung pada Jumlah embrio (calon anak) yang terdapat dalam uterus induk babi, sesuai dengan pernyataan Anderson (2000) yang menyatakan bahwa jumlah embrio (calon anak) yang terdapat dalam uterus induk babi akan berpengaruh terhadap bobot anak yang dilahirkan. Hal ini berkaitan erat dengan kemampuan embrio dalam bertahan hidup dan menyerap zat-zat makanan yang disalurkan melalui umbilicus placentalis (tali pusar). Babi Yorkshire terbukti sebagai salah satu bangsa babi yang baik dalam memelihara anak. Bangsa babi ini tidak hanya mempunyai jumlah anak lahir dan disapih yang banyak, tetapi juga sangat baik dalam menyusui anaknya sesuai dengan pernyataan Blakely dan Bade (1991).

\section{Duroc}

Rataan bobot lahir bangsa babi Duroc paling tinggi ada di tahun 2010 yaitu 1,70 kg/ekor/kelahiran. Nilai ragam paling tinggi sebesar 0,27 yaitu pada induk Duroc tahun 2012. Nilai koefisien keragaman paling tinggi 37,66 \% pada tahun 2012. Rataan jumlah anak sekelahiran tertinggi berada pada tahun 2011yaitu 10,3 ekor. Dengan koefisien keragaman terbesar yaitu 65,97. Hal ini menjelaskan bahwa terdapat sebanyak 37,66 \% keragaman diantara bobot lahir dan 65,97 \% keragaman jumlah anak sekelahiran bangsa babi Duroc di BPTU Babi dan Kerbau Siborong-borong. Bangsa babi Duroc terkenal dengan performansnya yang bagus. Hal ini terlihat dari bobot lahir yang dihasilkan cukup tinggi yaitu 1,70 kg/ekor/kelahiran. Bobot lahir yang tinggi dapat dipengaruhi oleh jumlah anak sekelahirannnya yang sedikit dan faktor genetiknya. Selain itu, hal lainnya yang mempengaruhi besar kecilnya bobot lahir adalah breed induk. Hal ini sesuai dengan pernyataan Eusebio (1980), yang menyatakan bahwa pengaruh bangsa terhadap bobot lahir anak babi adalah sangat nyata.

\section{Berkshire}

Rataan bobot lahir paling tinggi bangsa babi Berkshire adalah 1,522 kg/ekor/kelahiran yaitu terdapat pada tahun 2010. Rataan bobot lahir babi Berkshire secara berurut adalah 1,5 kg, 
$1,39 \mathrm{~kg}, 1,52 \mathrm{~kg}$ dan $1,43 \mathrm{~kg}$. Rataan nilai ragam terbesar berada pada tahun 2012 yaitu 0,081 dengan KK sebesar 19, $01 \%$. Besar kecilnya bobot lahir ternak babi ditentukan oleh beberapa faktor. Salah satunya jumlah anak sekelahiran. Rataan jumlah anak sekelahiran paling tinggi terdapat pada tahun 2010 yaitu 7,75 ekor per kelahiran dengan KK sebesar 30,45\%. Rata-rata paritas untuk bangsa murni Berkshire berkisar antara 5-14 ekor babi. Jika ditangani dengan manajemen yang baik, maka rata-rata litter size untuk jenis babi Berkshire adalah 9,0 ekor (McMullen, 2006).

\section{KESIMPULAN}

Keragaman bobot lahir dan jumlah anak sekelahiran ternak babi bangsa murni Australia (Landrace, Yorkshire, Duroc dan Berkshire) selama 4 tahun bervariasi mulai dari sedang sampai tinggi. Bangsa babi yang paling baik digunakan sebagai pembibit di Balai Pembibitan Ternak Unggul (BPTU) adalah bangsa babi Yorkshire, karena mempunyai jumlah anak sekelahiran yang tinggi dan sifat keindukan yang baik dan apabila dilihat dari besarnya nilai keragaman, bangsa ternak yang paling beragam dan dapat dipertimbangkan untuk diseleksi sebagai pembibit adalah bangsa babi Duroc.

\section{DAFTAR PUSTAKA}

Anderson, LL., 2000. Pigs. In Hafez ESE, Hafez B, editor. Reproduction in farm Animals. $7^{\text {th }}$ Ed. USA: Williams \& Wilkins.

Babot, D., J.L. Noguera dan L. Alfonso, J. Estany. 1994. Influence of management effects and comparison group size on the prediction of breeding values for litter size in pigs. Dalam: C. Smith, J. S Gavora, B. Benkel, J. Chenais, W. Fairfull, J. P. Gibson, B. W. Kennedy dan E. B. Burnside (Editor). $5^{\text {th }}$ World Congress on Genetics Applied to Livestock Production. Organizing Committee, Canada.

Blakely, J dan D.H Bade., 1991. Ilmu Peternakan. Penerbit Gajah Mada University Press.

Ditjennak, 2011. Potensi Babi Indonesia. http://Www.Deptan.Go.Id. Diakses 12 maret 2012 pukul 13.00

Eusebio, J. A. 1980. Pig Production in the Tropic. Intermediate Tropical Agriculture Series. University of the Philipines, Los Banos

Geisert, RD. and R.A.M. Schmitt. 2002. Early embryonic survival in the pig: Can it be improved ? J. Anim. Sci. 80:54-85.

Hardjosubroto, 1994. Aplikasi Pemuliabiakan Ternak di Lapangan. Penerbit PT Gramedia Widiasarana Indonesia, Jakarta. 
McMullen, K. L., 2006. Berkshire Swine Production and Marketing, "Supported by the Value Chain Partnerships for a Sustainable Agriculture (VCPSA) and the Pork Niche Market Working Group (PNMWG) using funds from the W.K. Kellogg Foundation”. Iowa State University Extension Swine Field Specialist, USA

Sastrosupardi, A., 2000. Rancangan Percobaan Praktis Bidang Pertanian Edisi Revisi. Penerbit Kanisius, Yogyakarta.

Siagian, P. H. 1985. Studi tentang performans dari bangsa ternak babi Landrace, Duroc dan Yorkshire. Institut Pertanian Bogor. Proyek Peningkatan/Pengembangan Perguruan Tinggi, Bogor.

Sihombing, D. T. H., 1997. Ilmu Beternak Babi, UGM press, Yogyakarta. 